\title{
Sugarcane Tolerance to Ratoon Eradication with Glyphosate Determined by Physiological Responses ${ }^{1}$
}

\author{
Tolerância da Soqueira da Cana-de-Açúcar à Erradicação com Glyphosate Determinada por \\ Respostas Fisiológicas
}

\author{
SILVA, M.A. ${ }^{2}$, ARANTES, M.T. ${ }^{2}$, OLIVER, R. ${ }^{2}$, and BRUNELLI, M.C. ${ }^{2}$
}

\begin{abstract}
This study aimed to evaluate the tolerance of sugarcane cultivars to ratoon eradication under different glyphosate rates by means of physiological responses. Therefore, a trial was carried out in randomized complete blocks with $4 \times 4$ factorial design (cultivars $\mathrm{x}$ rates) totaling 16 treatments with four replicates. The cultivars IAC91-5155, IACSP93-3046, and IAC86-2480 and IAC87-3396 and the glyphosate rates $0 \mathrm{~g} \mathrm{ha}^{-1} ; 1,920 \mathrm{~g} \mathrm{ha}^{-1}$; $2,400 \mathrm{~g} \mathrm{ha}^{-1} ; 2,880 \mathrm{~g} \mathrm{ha}^{-1}$ were tested. The variables analyzed were percentage of tiller mortality, quantum efficiency of PSII $(F v / F m)$ and SPAD index. The results showed that there are differences among sugarcane cultivars for tiller eradication and for physiological responses with glyphosate different rates. The rate of 2,880 $\mathrm{g} \mathrm{ha}^{-1}$ was the most efficient in eliminating sugarcane tillers. The cultivars IAC86-2480, IAC87-3396 and IACSP93-3046 were the most sensitive and the IAC91-5155 tolerated, for a longer period of time, the damage to the photosynthetic apparatus of the ratoons caused by glyphosate desiccation. Due to different responses, different managements should be considered for eliminating ratoons of different cultivars.
\end{abstract}

Keywords: Saccharum spp., varieties, tillers, chlorophyll fluorescence, SPAD, herbicide.

RESUMO - O presente trabalho teve como objetivo avaliar a tolerância de cultivares de cana-deaçúcar à erradicação de soqueiras com diferentes doses de glyphosate por meio de respostas fisiológicas. Para isso, um ensaio foi desenvolvido no delineamento experimental de blocos ao acaso em esquema fatorial $4 \times 4$ (cultivares $x$ doses), totalizando 16 tratamentos com quatro repetições. Foram utilizados os cultivares IAC91-5155, IACSP93-3046, IAC86-2480 e IAC87-3396 tratados com as doses de glyphosate $0,1.920,2.400, e 2.880 \mathrm{~g} \mathrm{ha}^{-1}$. As variáveis analisadas foram porcentagem de perfilhos mortos, eficiência quântica do FSII (Fv/ Fm) e indice SPAD. Há diferenças entre cultivares de cana-de-açúcar quanto à eliminação de perfilhos e a respostas fisiológicas a diferentes doses de glyphosate. A dose de $2.880 \mathrm{~g} \mathrm{ha}^{-1}$ foi a mais eficiente em eliminar perfilhos de cana-de-açúcar. Os cultivares IAC86-2480, IAC87-3396 e IACSP93-3046 foram os mais sensiveis, e o IAC91-5155 tolerou por mais tempo os danos promovidos no aparato fotossintético à dessecação das soqueiras pelo glyphosate. Devido às respostas diferenciadas, manejos distintos devem ser considerados para a eliminação das soqueiras de diferentes cultivares.

Palavras-chave: Saccharum spp., variedades, perfilhos, fluorescência da clorofila, SPAD, herbicida.

\section{INTRODUCTION}

Eradication of sugarcane ratoons, aimed at cropland renovation, is a farming operation widely used in areas with low levels of productivity after approximately five to six years of cultivation. One of the techniques currently employed in sugarcane plantations for eradicating ratoons is chemical eradication, aimed at reusing sugarcane straw and

\footnotetext{
Recebido para publicação em 1.8.2013 e aprovado em 20.1.2014.

Universidade Estadual Paulista (UNESP), Botucatu-SP, Brasil, <marcelosilva@fca.unesp.br>.
} 
improving the physical and chemical conditions of the soil (Silva $\&$ Rossetto, 2002).

Therefore, the preparation of the subsequent planting begins with the removal of previous ratoons by applying selective herbicides. After complete desiccation, ratoons are usually destroyed mechanically (Coleti, 2008). This procedure may provide for the use of the techniques of no-till farming or minimum tillage, which are conservationist at the time of renovation of sugarcane plantations, which, combined with the straw remaining from mechanized harvesting of sugarcane, maintain a layer of mulch, which contributes to the improvement of the physical and chemical conditions of the soil for the maintenance of larger inventories of organic matter (Silva \& Rossetto, 2002).

There are several products that can be used for this purpose; however, glyphosate is the oldest and the most frequently used. The herbicide glyphosate, inhibitor of 5enolpyruvylshikimate-3-phosphate (EPSP) synthase, acts by inhibiting the synthesis route of essential aromatic amino acids, phenylalanine, tyrosine and tryptophan, which are precursors of other products, such as lignin, alkaloids, flavonoids and benzoic acids (Kruse et al. 2000). Symptoms of their action on plants include "yellowing" of meristems, necrosis and cell death within days or weeks (Amarante Junior et al., 2002). Cell death occurs through the degradation of photosynthetic pigments, which are responsible for the transformation of light energy into chemical energy. One of these pigments is chlorophyll, which can be considered indicative of leaf photosynthetic efficiency, and is used to quantify the tolerance or susceptibility of sugarcane cultivars.

Several sugarcane cultivars have different morphological, physiological and biochemical properties, and they may display different behavior as to their tolerance to specific herbicides (Galon et al., 2010, Arantes et al., 2013). According to Lorenzi (1983), sugarcane cultivars have different degrees of susceptibility to the complete destruction of the ratoons by glyphosate, and rates may range between 1,440 and 3,360 $\mathrm{g} \mathrm{ha}^{-1}$.

Silva et al. (2006) evaluated the sensitivity of four sugarcane cultivars by the mortality of ratoon tillers after application of glyphosate under $2,400 \mathrm{~g} \mathrm{ha}^{-1}$, and they found that this rate was not sufficient to eliminate $100 \%$ of the tillers. However, for three cultivars, tiller desiccation was greater than $80 \%$, while for one cultivar, eradication was below $60 \%$, which shows that the cultivars responded differently. More recently, Adriano et al. (2013) studied phenotypic and biochemical changes in different sugarcane cultivars in response to glyphosate and concluded that there was a product-saving rate to eradicate each cultivar. However, the activity of enzymes shikimate dehydrogenase and $\alpha$-esterase were not associated with tolerance to the desiccation of the plants.

Physiological variables have been used as tools for selectivity of sugarcane cultivars to various herbicides and mixtures (Galon et al., 2009; Souza et al., 2009, Arantes et al., 2013), but there are no studies of these responses to glyphosate when removing plants for renovation of sugarcane plantations. In this context, the present study aimed to evaluate the physiological responses of sugarcane cultivars under different glyphosate rates for ratoon eradication.

\section{MATERIAL AND METHODS}

The experiment was conducted in the field, in an area near the town of Jaú, Brazil, located at coordinates $22^{\circ} 15^{\prime} \mathrm{S}$ and $48^{\circ} 34^{\prime} \mathrm{W}$, at an average altitude of $580 \mathrm{~m}$.

The target area was harvested on September $7^{\text {th }}, 2010$; the sugarcane was in its fifth harvest cycle. The experiment was conducted in randomized blocks with a $4 \times 4$ factorial design, totaling 16 treatments resulting from the combination of four cultivars (IAC91-5155, IACSP93-3046, IAC86-2480 and IAC87-3396) and four glyphosate rates (0, $1,920,2,400$ and $2,880 \mathrm{~g} \mathrm{ha}^{-1}$ ), with four replications. The plots consisted of five rows measuring $6 \mathrm{~m}$, spaced at $1.40 \mathrm{~m}$, in a total area of $42 \mathrm{~m}^{2}$.

The product was applied at 64 days after sugarcane cutting, with a $\mathrm{CO} 2$ pressurized backpack sprayer outfitted with four AXI 11002 flat fan nozzles, spaced at $40 \mathrm{~cm}$, with constant pressure of $300 \mathrm{kPa}$ and spray volume of $400 \mathrm{~L} \mathrm{ha}^{-1}$. The average environmental 
conditions at application were: relative humidity of $75 \%$ and an air temperature of $30{ }^{\circ} \mathrm{C}$

The live tillers of each plot within the floor area were counted before application and the live and dead tillers were counted at $7,14,21$ and 28 days after application (DAA) to quantify the action of glyphosate. The tillers were considered as dead when they were entirely yellow or dry. The three central rows of the plots were used for this purpose.

Chlorophyll fluorescence $\left(F_{v} / F_{m}\right)$ was evaluated with a portable modulated fluorometer (OS-30p Chlorophyll Fluorometer, Opti-Sciences, Hudson, USA). Readings of $F_{v} / F_{m}$ were made with special clips for darkening five leaves +1 per plot for 30 minutes. Subsequently, the value of the variable was obtained by the methodology of Maxwell \& Johnson (2000), where $F_{m}$ is the maximum fluorescence intensity in which all reactions of photosystem II (PSII) are closed; $F_{o}$ is the minimum fluorescence intensity, when the PSII reaction centers are open; $F_{v}$ is the variable fluorescence, calculated by the difference between maximum and minimum fluorescence intensity $\left(F_{v}=F_{m}-F_{o}\right)$.
SPAD readings were made with a SPAD502 chlorophyll meter (Minolta Corp., Ramsey, New Jersey, USA). Measurements were made on the same five leaves +1 that had been used to measure $F_{v} / F_{m}$; the mean of the plot was subsequently obtained.

Readings of both fluorescence and the SPAD index were made between 8 and 10 o'clock. Assessments for both the quantum efficiency of photosystem II and the SPAD index were made at $0,7,14,21,28$ DAA.

The experimental data were subjected to analysis of variance (F-test), and the means were compared by Tukey's test at 5\% probability.

\section{RESULTS AND DISCUSSION}

There was no significant difference for percentage of tiller mortality between the cultivars at 7,14 and 28 DAA of glyphosate. Statistical difference was observed only at 21 DAA (Table 1), while significant effect of glyphosate rates was observed on tiller mortality in all periods. A significant effect was observed for the interaction between cultivars and glyphosate rates on tiller mortality at 21

Table 1 - Values of mean squares and coefficient of variation of analysis of variance for percentage of tiller mortality, quantum efficiency of photosystem II $\left(F_{v} / F_{m}\right)$ and SPAD index, as a function of sugarcane varieties and glyphosate rates at 7, 14, 21 and 28 days after glyphosate application

\begin{tabular}{|c|c|c|c|c|}
\hline \multirow{3}{*}{ Treatment } & \multicolumn{4}{|c|}{ Tiller mortality $(\%)$} \\
\hline & \multicolumn{4}{|c|}{ Days after application } \\
\hline & 7 & 14 & 21 & 28 \\
\hline Cultivar (C) & $8.16^{\mathrm{ns}}$ & $45.10^{\mathrm{ns}}$ & $58.95 * *$ & $47.47^{\mathrm{ns}}$ \\
\hline Rate $(\mathrm{R})$ & $43.11 * *$ & $338.55^{* *}$ & $52.20 * *$ & $1425.64 * *$ \\
\hline $\mathrm{C} \times \mathrm{R}$ & $1.80^{\mathrm{ns}}$ & $22.30^{\mathrm{ns}}$ & $16.39 *$ & $110.76^{* *}$ \\
\hline \multirow[t]{2}{*}{$\mathrm{CV}(\%)$} & 24.39 & 17.70 & 5.48 & 5.96 \\
\hline & \multicolumn{4}{|c|}{ Quantum efficiency of photosystem II $(F v / F m)$} \\
\hline Cultivar (C) & $0.000^{\mathrm{ns}}$ & $0.006^{* *}$ & $0.037^{* *}$ & $0.018 * *$ \\
\hline Rate $(\mathrm{R})$ & $0.103 * *$ & $0.277 * *$ & $0.573 * *$ & $0.609 * *$ \\
\hline $\mathrm{C} \times \mathrm{R}$ & $0.001^{\mathrm{ns}}$ & $0.001^{\mathrm{ns}}$ & $0.010 * *$ & $0.009 * *$ \\
\hline \multirow[t]{2}{*}{$\mathrm{CV}(\%)$} & 5.13 & 5.69 & 5.54 & 10.93 \\
\hline & \multicolumn{4}{|c|}{ SPAD index } \\
\hline Cultivar (C) & $24.298^{* *}$ & $5.923^{\mathrm{ns}}$ & $51.436^{* *}$ & $55.782 * *$ \\
\hline Rate (R) & $826.761 * *$ & $1406.832^{* *}$ & $2270.156^{* *}$ & $2392.221^{* *}$ \\
\hline $\mathrm{C} \times \mathrm{R}$ & $2.76^{* *}$ & $4.710^{* *}$ & $21.890^{* *}$ & $26.822 * *$ \\
\hline CV $(\%)$ & 3.83 & 5.5 & 4.31 & 5.58 \\
\hline
\end{tabular}

$\mathrm{ns}, *$, and $* *$ non-significant, significant at $5 \%$ and at $1 \%$, respectively. 
and 28 DAA (Table 1), which was indicative of the most appropriate times to identify differential responses between the cultivars and the rates in ratoon eradication.

Further analysis of this interaction for percentage of tiller mortality (Figure 1) shows greater sensitivity of cultivar IAC86-2480 to the lowest glyphosate rate $\left(1,920 \mathrm{~g} \mathrm{ha}^{-1}\right.$ at 21 DAA), with approximately $60 \%$ of dead tillers, while cultivars IAC91-5155 and IACSP93-3046 were less sensitive, with approximately $35-40 \%$ of tillers removed (Figure 1A). At the same evaluation period, but using the intermediate rate $\left(2,400 \mathrm{~g} \mathrm{ha}^{-1}\right)$ and the largest rate $\left(2,880\right.$ a.i. $\left.\mathrm{ha}^{-1}\right)$, the cultivar IACSP933046 showed similar sensitivity to that of IAC86-2480 and IAC87-3396, while IAC915155 had the lowest percentage of dead tillers, between 45 and $50 \%$ (Figure 1A). The rate of $2,880 \mathrm{~g} \mathrm{ha}^{-1}$ controlled approximately $80 \%$ of the tillers of the cultivars IAC86-2480, IAC873396 and IACSP93-3046, and only $50 \%$ of IAC91-5155 at 21 DAA.

Differential responses of sugarcane cultivars to herbicides have been reported by several authors (Ferreira et al., 2005, Souza et al., 2009; Galon et al., 2009, 2010; Adriano et al., 2013, Arantes et al., 2013). Souza et al.
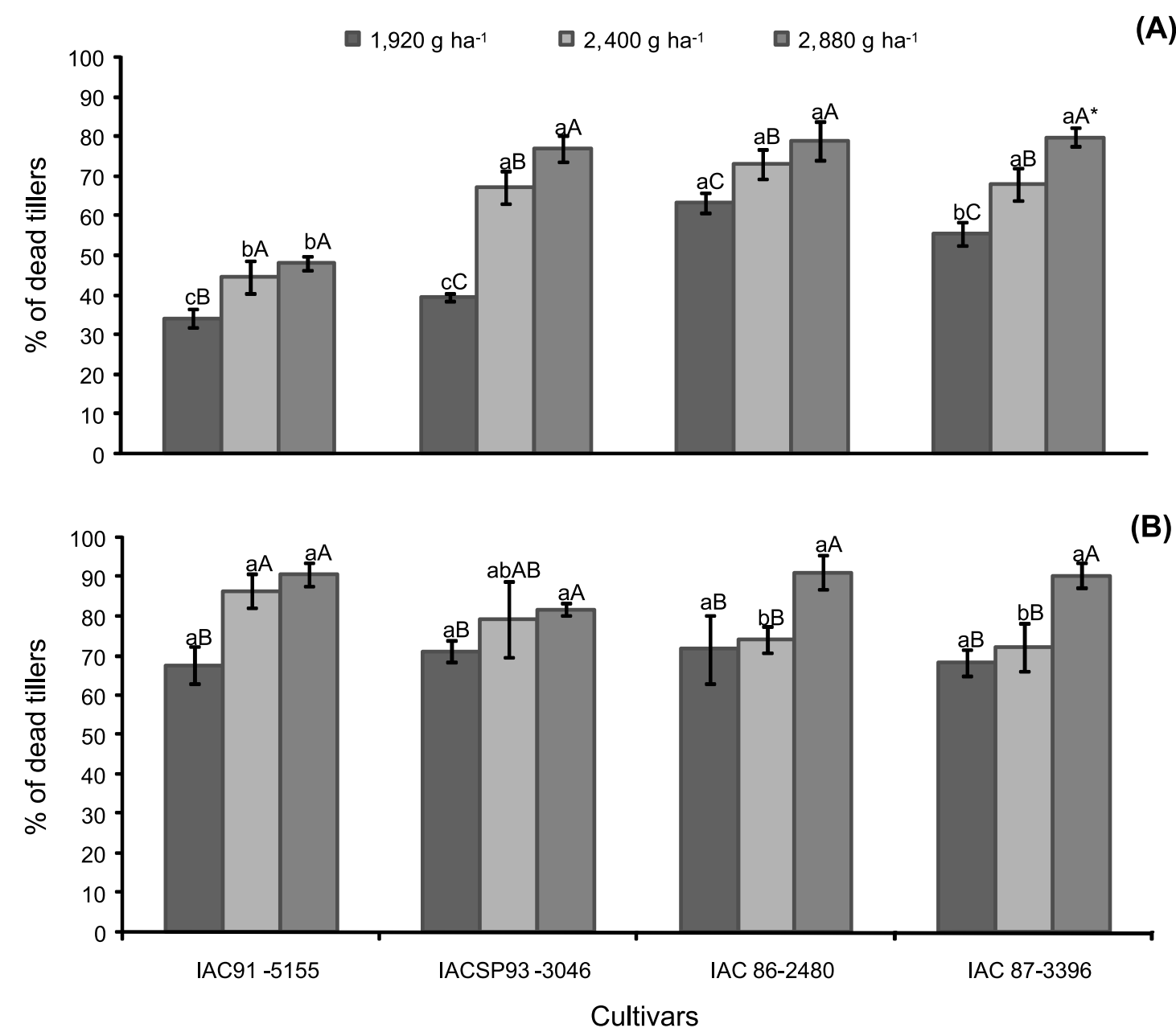

* Means followed by different letters, lowercase letters between cultivars under the same rate and capital letters between rates in the same
cultivar, differ at $5 \%$ probability by Tukey's test.

Figure 1 - Further analysis of the interaction cultivar x rate for percentage of dead sugarcane tillers at 21 (A) and 28 (B) days after glyphosate application. 
(2009) did not report IAC86-2480 and IACSP933046 as sensitive to herbicides. However, these authors evaluated tolerance to products with photosynthesis-inhibiting mode of action and weed control rates. In a controlled environment, Adriano et al. (2013) classified IACSP93-3046 as tolerant to glyphosate compared to the cultivar RB72454. For such measurement, they used the variable percentage of symptoms of intoxication, where this cultivar had nearly $70 \%$ of symptoms at 20 days after application of $2,880 \mathrm{~g} \mathrm{ha}^{-1}$ and standard of $70-80 \%$. Silva et al. (2006) had previously classified IAC91-5155 as tolerant to tiller eradication when glyphosate was applied at 2,400 $\mathrm{g} \mathrm{ha}^{-1}$.

Knowledge of glyphosate sensitivity of sugarcane cultivars for ratoon eradication purposes is an important tool when deciding the rate to be applied, because this may result in using a greater or lesser amount of the product. The ratoons of the cultivars IAC862480, IACSP93-3046 and IAC87-3396 can be controlled at the recommended rate of 2,400 g a.i. ha ${ }^{-1}$ after 21 DAA, while the lower percentage of tiller eradication in IAC91-5155 may indicate difficulty in managing the desiccation of the ratoons. As a result, longer time or higher rates of glyphosate are required for this application to achieve greater efficiency.

At 28 DAA, there was a higher percentage of control (above $80 \%$ ) for tillers of the cultivar IAC91-5155 at 2,400 and 2,880 $\mathrm{g} \mathrm{ha}^{-1}$. There was also greater tiller control for IACSP93-3046 with these two higher rates, but the percentage of desiccation was around $80 \%$. In contrast, for the cultivars IAC86-2480 and IAC87-3396, only the rate of $2,880 \mathrm{~g} \mathrm{ha}^{\dagger 1}$ could effectively control around $90 \%$ of the tillers. Under the rate of 1,920 $\mathrm{g} \mathrm{ha}^{\dagger 1}$, control was below 70\% (Figure 1B); thus, it was a low rate for desiccating the ratoons of these cultivars.

The analysis of variance for the maximum quantum efficiency of photosystem II $\left(F_{v} / F_{m}\right)$ revealed a significant effect of sugarcane cultivars between 14 and 28 DAA and of glyphosate rates in all evaluation periods, while significant interactions among cultivars and rates were observed at 21 and 28 DAA (Table 1).
No effect of the control treatment $\left(0 \mathrm{~g} \mathrm{ha}^{-1}\right)$ was observed in chlorophyll fluorescence of the four cultivars in the evaluated periods, with values ranging between 0.75 and 0.80 (Figure 2A), which corroborates the findings of Silva et al. (2007), who reported that the stress-free values of $F_{v} / F_{m}$ in cane sugar are close to 0.80 . For rates above $1,920 \mathrm{~g}^{\text {ha }}{ }^{-1}$, there was a reduction in $F_{v} / F_{m}$ values with increased evaluation time, with different responses among cultivars after 21 DAA, with higher reductions for cultivars IAC86-2480 and IAC873396 (Figure 2B). The highest interference in the quantum efficiency of PSII occurred under the rates of 2,400 and $2,880 \mathrm{~g} \mathrm{ha}^{-1}$, with values ranging from 0.34 (IAC86-2480) to 0.49 (IAC91-5155) and from 0.30 (IAC87-3396) to 0.39 (IAC91-5155), respectively, at 28 DAA (Figure 2C, D).

The photosynthetic apparatus of cultivars IAC86-2480, IAC87-3396 and IACSP93-3046 were more affected by glyphosate; in contrast, the lowest damage to the quantum efficiency of PSII $\left(F_{v} / F_{m}\right)$ was observed in IAC91-5155 (Figure 2B, C and D). Thus, the cultivar IAC91-5155 takes more time to show the effects of glyphosate application on its photosynthetic apparatus. Queiroz et al. (2011) reported that IAC91-5155 is tolerant to abiotic stresses such as drought and soil acidity, and its physiological and biochemical properties are less altered by these factors. According to Baker (2008), herbicides that affect the synthesis of chlorophyll modify the metabolism of plants, changing patterns of fluorescence emission of chlorophyll $a$. This effect causes interference with the flow of electrons and reduction of ATP production by inhibiting the activity of ATP synthase in the process of phosphorylation (Wakabayashi \& Böger, 2004), which led to a higher percentage of tiller mortality in the susceptible cultivars.

A significant effect of cultivars and rates in the variable SPAD index was observed in the four evaluation times, except at 14 DAA, when the effect of cultivars was not significant. A statistical significant effect on the variable SPAD index was observed in all periods for the interaction between sugarcane cultivars $\mathrm{x}$ glyphosate rates (Table 1). 

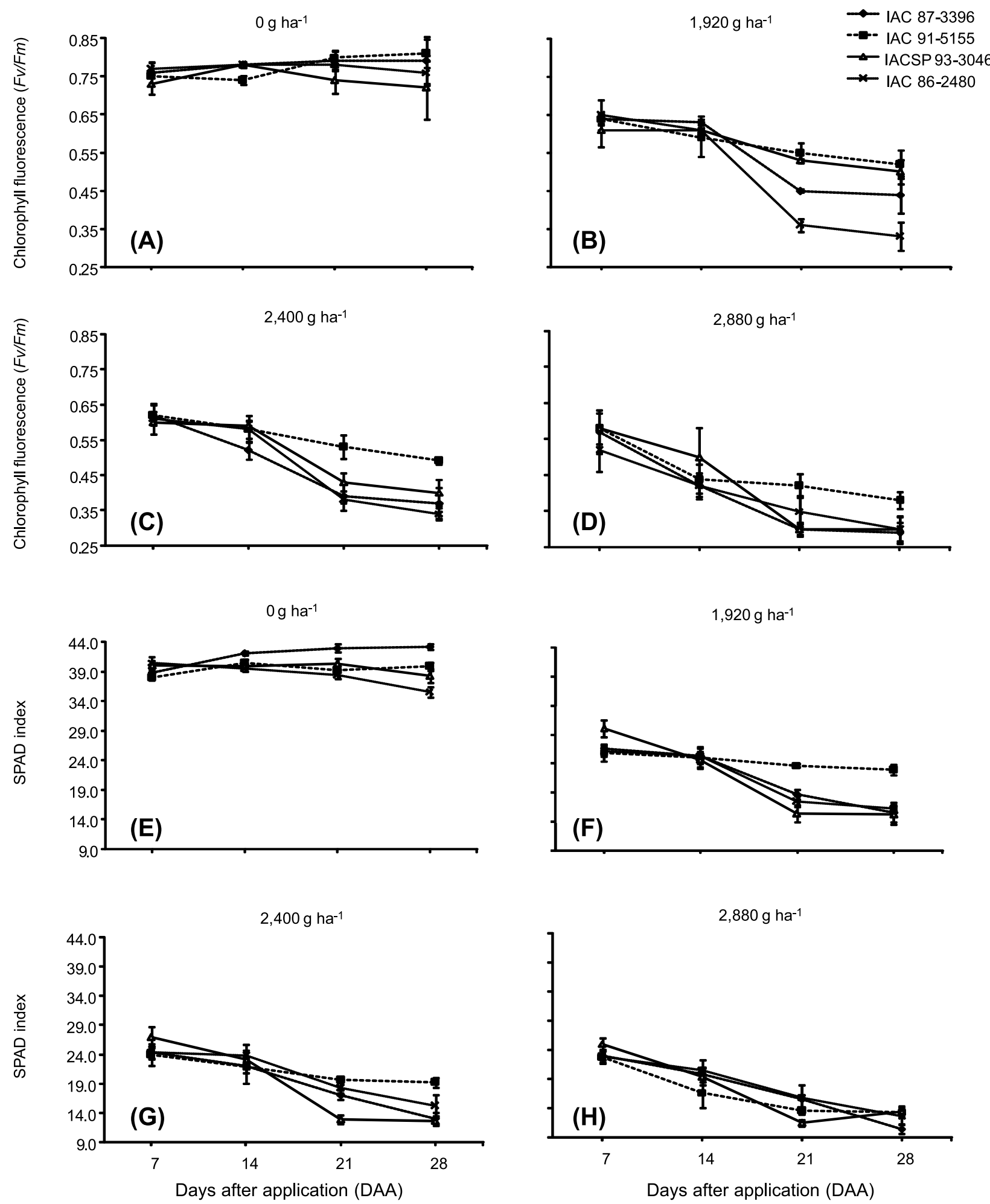

(Each symbol indicates the mean value of four replicates \pm standard deviation).

Figure 2 - Further analysis of the interaction cultivar x rate regarding the maximum quantum efficiency of PSII ( $\left.F_{v} / F_{m}\right)(\mathrm{A}, \mathrm{B}, \mathrm{C}$ and D) and SPAD index (E, F, G and H) as a function of sugarcane cultivars at 7, 14, 21, 28 days after the application of the following glyphosate rates: $0,1,920,2,400$ and $2,880 \mathrm{~g} \mathrm{ha}^{-1}$. 
One way to describe a sugarcane cultivar is by the shade of green of its leaves, so the observed differences between cultivars under the rate of $0 \mathrm{~g} \mathrm{ha}^{-1}$ (Figure 2E) indicate only those inherent in genetics itself. With rates above $1,920 \mathrm{~g} \mathrm{ha}^{-1}$, a strong reduction was observed in SPAD index values. The rate of $2,880 \mathrm{~g} \mathrm{ha}^{-1}$ reduced this index indiscriminately in all the cultivars, with values ranging between 25 (at $7 \mathrm{DAA}$ ) and 10 (at $28 \mathrm{DAA}$ ) (Figure 2H). Under the rates of 1,920 and $2,400 \mathrm{~g} \mathrm{ha}^{-1}$, cultivars showed differential responses; IAC91-5155 was less affected, unlike the others, especially at 28 DAA (Figure 2F, G). For IAC91-5155, under the rate of $1,920 \mathrm{~g} \mathrm{ha}^{-1}$, there was little variation in SPAD between 7 and 28 DAA, with values ranging from 25.9 to 22.9 , respectively (Figure $2 \mathrm{~F}$ ), while in the other cultivars, values respectively ranged from 28 (7 DAA) to16 (28 DAA), on average. Under the rate of 2,400 $\mathrm{g} \mathrm{ha}^{-1}$, IAC86-2480, IACSP93-3046 and IAC87-3396 were the most affected cultivars, especially at 28 DAA, with average values of SPAD index of 14 , while a value of 19.2 was observed for IAC9-5155 (Figure 2G).

Adriano et al. (2013) also reported a marked decrease in the SPAD index with higher glyphosate rates, regardless of cultivar, and they recommended rates below $3.600 \mathrm{~g} \mathrm{ha}^{-1}$ as the most effective for cultivar differentiation.

As the SPAD index is indicative of the green color of leaves, researchers have reported the existence of a relationship between greening rate and leaf chlorophyll content in various plant species (Argenta et al., 2001; Jifon et al., 2005). It was observed that IAC91-5155 had green leaves for longer under the rates of 1,920 and $2,400 \mathrm{~g} \mathrm{ha}^{-1}$, i.e., they tolerated the degradation of their photosynthetic pigments by the action of glyphosate. These pigments, mainly chlorophyll, are responsible for the conversion of light energy into chemical energy (Streit et al., 2005); thus, the ability of this cultivar to keep green provided the survival of tillers for a longer time.

Several explanations are mentioned for plant tolerance to EPSP sinthase-inhibiting herbicides. Factors other than genetic ones may be involved, such as the stage of crop development, leaf morphology, herbicide metabolism, the rate used, among others (Christoffoleti et al., 2009). Thus, for desiccating the ratoon of IAC91-5155, the use of higher rates should be considered.

In conclusion, there are differences between sugarcane cultivars as regards tiller eradication and physiological responses under the action of different glyphosate rates: sugarcane cultivars IAC86-2480, IAC87-3396 and IACSP93-3046 were the most sensitive, and IAC91-5155 was more tolerant to damage to the photosynthetic apparatus of the ratoons by glyphosate desiccation.

Also, the rate of $2,880 \mathrm{~g} \mathrm{ha}^{-1}$ was the most effective in eliminating about $90 \%$ of tillers of most sugarcane cultivars at 28 days after glyphosate application.

Therefore, given the different physiological responses between sugarcane cultivars as regards glyphosate application, the management of different herbicide rates should be considered for ratoon eradication.

\section{ACKNOWLEDGEMENTS}

We would like to thank the National Council for Scientific and Technological Development (CNPq) for the award of scholarships to the first and third authors. We are also grateful to the Coordination of Improvement of Higher Education Personnel (CAPES) for granting scholarships to the second and fourth authors.

\section{LITERATURE CITED}

ADRIANO, R. C. et al. Phenotipic and biochemical responses of sugarcane cultivars to glyphosate application. Sugar Technol., v. 15, n. 2, p. 127-135, 2013.

AMARANTE JUNIOR, O. P. et al. Glifosato: propriedades, toxicidade, usos e legislação. Química Nova, v. 25, n. 4, p. 589-593, 2002.

ARANTES, M. T. et al. Respostas fisiológicas de cultivares de cana-de-açúcar a herbicidas seletivos. Biosci. J., v. 29, n. 5, p. 1206-1214, 2013.

ARGENTA, G. et al. Teor de clorofila na folha como indicador do nível de N em cereais. Ci. Rural, v. 31, n. 4, p. 715-722, 2001.

Planta Daninha, Viçosa-MG, v. 32, n. 1, p. 207-214, 2014 
BAKER, N. R. Chlorophyll fluorescence: a probe of photosynthesis in vivo. Ann. Rev. Plant Biol., v. 59, p. 89-113, 2008.

CHRISTOFFOLETI, P. J. et al. Resistência de plantas daninhas aos herbicidas inibidores da EPSPs. In: VELINI, E. D. et al. Glyphosate. Botucatu: Fepaf, 2009. p. 309-355.

COLETI, J. T. O preparo de solo sob a ótica conservacionista. In: DINARDO-MIRANDA, L. L. et al. Cana-de-açúcar. Campinas: Instituto Agronômico, 2008. p. 573-584.

FERREIRA, E. A. et al. Sensibilidade de cultivares de canade-açúcar à mistura trifloxysulfuron-sodium + ametryn.

Planta Daninha, v. 23, n. 1, p. 93-99, 2005.

GALON, L. et al. Influência de herbicidas na atividade fotossintética de genótipos de cana-de-açúcar.

Planta Daninha, v. 27, n. 3, p. 591-597, 2009.

GALON, L. et al. Tolerância de novos genótipos de cana-deaçúcar a herbicidas. Planta Daninha, v. 28, n. 2, p. 329-338, 2010.

JIFON, J. L. et al. Growth environment and leaf anatomy affect nondestructive estimates of chlorophyll and nitrogen in Citrus sp. leaves. J. Am. Soc. Hortic. Sci., v. 130, n. 2, p. 152-158, 2005.

KRUSE, N. D. et al. Herbicidas inibidores da EPSPS: revisão de literatura. R. Bras. Herb., v. 1, n. 2, p. 139-146, 2000.
LORENZI, H. Pragas da cultura da cana-de-açúcar. In: REUNIÃO TÉCNICA AGRONÔMICA, 2., 1983, Piracicaba. Anais... São Paulo: Copersucar, 1983. p. 59-82.

MAXWELL, K.; JOHNSON, G. N. Chlorophyll fluorescence: a pratical guide. J. Exper. Bot., v. 51, n. 345, p. 659-668, 2000.

QUEIROZ, R. J. B. et al. Biochemical and physiological responses of sugarcane cultivars to soil water deficiencies. Sci. Agric., v. 68, n. 4, p. 469-476, 2011.

SILVA, M. A. et al. Tipos de colheita e épocas de aplicação de glifosato na erradicação de soqueiras de cana-de-açúcar. Pesq. Agropec. Bras., v. 41, n. 1, p. 43-49, 2006.

SILVA, M. A. et al. Use of physiological parameters as fast tools to screen for drought tolerance in sugarcane. Braz. J. Plant. Physiol., v. 19, n. 3, p. 193-201, 2007.

SILVA, M. A.; ROSSETTO, R. Diferenças varietais na eliminação química de soqueiras de cana-de-açúcar. STAB Açúcar Álcool Subp., v. 20, n. 1, p. 24-27, 2002.

SOUZA, J. R. et al. Tolerância de cultivares de cana-de-açúcar a herbicidas aplicados em pós-emergência. Bragantia, v. 68, n. 4, p. 941-951, 2009.

STREIT, N. M. et al. As clorofilas. Ci. Rural, v. 35, n. 1, p. 748-755, 2005.

WAKABAYASHI, K.; BÖGER, P. Phytotoxic sites of action for molecular design of modern herbicides: the photosynthetic electron transport system. Weed Biol. Manag., v. 4, n. 1, p. 8-18, 2004. 